\title{
About a Case of Neurotic Angioedema Induced by Angiotensin Converting Enzyme Inhibitor
}

\author{
Rakotoniaina Andriamiarimbola Irène ${ }^{1}$, Fenomana Jocia ${ }^{2}$, Riel Andry Mampionona ${ }^{3}$, \\ Rasamindrakotroka Andry ${ }^{4}$
}

${ }^{1}$ Laboratory Department, University Hospital Mitsinjo Betanimena, Tuléar, Madagascar

${ }^{2}$ Laboratory Department, University Hospital Tambohobe, Fianarantsoa, Madagascar

${ }^{3}$ Reanimation Department, University Hospital Tanambao, Tuléar, Madagascar

${ }^{4}$ Laboratory of Immunology Department, University Hospital HJRA, Antananarivo, Madagascar

Email:paps11380@yahoo.fr

How to cite this paper: Irène, R.A., Jocia, F., Mampionona, R.A. and Andry, R. (2017) About a Case of Neurotic Angioedema Induced by Angiotensin Converting Enzyme Inhibitor. Case Reports in Clinical Medicine, 6, 295-300.

https://doi.org/10.4236/crcm.2017.611034

Received: October 17, 2017

Accepted: November 12, 2017

Published: November 15, 2017

Copyright $\odot 2017$ by authors and Scientific Research Publishing Inc. This work is licensed under the Creative Commons Attribution International License (CC BY 4.0).

http://creativecommons.org/licenses/by/4.0/

\begin{abstract}
Neurotic angioedema may be secondary to ACE (Angiotensin-converting enzyme) inhibitor. From a case of neurotic angioedema in a hypertensive man under ACE (Angiotensin-converting enzyme) inhibitor, we expose the clinical characteristics typical of the edema and its evolution. A 73-year-old man has consulted for edema of the face and redness of the palmar surface of the hand not pruriginous for 2 days. He has already had conventional anti-edematous treatments but no changes. In the absence of a technical platform, no paraclinical examination was carried out. The cessation of ACE inhibitor and the administration of tranexamic acid were made immediately. Signs regressed within 24 hours. Neurotic angioedema is a diagnostic problem in countries where biological examination is still limited and if practitioners are unaware of the possibility of its occurrence during IEC treatment. While the patient's prognosis depends on the precocity of management.
\end{abstract}

\section{Keywords}

Neurotic Angioedema, ACE inhibitor, Diagnosis, Treatment

\section{Introduction}

Bradykinetic angioedema is rare $1 / 50,000$ to $1 / 500,000$ individual of the general population [1] [2]. ACE inhibitors may cause angioedema in $0.1 \%$ to $0.6 \%$ of treated patients [3] [4]. Angioedema is characterized by localized and sudden swelling of subcutaneous tissues or submucosal [5] [6]. Angioedema (AO) therefore corresponds to a deep urticaria where the edema is hypodermic [7]. Its 
location is very varied but more readily touches the face and the neck [8]. Several drugs are incriminated in angioneurotic edema including ACE inhibitor (Angiotensin-converting enzyme) [9] [10] and [11]. The occurrence of neurotic angioedema when taking ACE is a rare but frequent complication compared to post-ARA II neurotic angioedema [12]. The frequency of occurrence varies according to the studies [13] [14]. Its incidence is $0.68 \%$ in the Causasians whereas in the black subjects the incidence is multiplied by 4 to 5 compared to the other populations [8] [12] [15] [16]. The occurrence of neurotic angioedema may be delayed compared to the initiation of treatment. It is due to the accumulation of bradykinin. ACE inhibitors inhibit angiotensin converting enzyme. ACE is an analogue of kininase II. Kininase promotes the degradation of bradykinin, by inhibiting the conversion enzyme, thus reducing the degradation of bradykinin. There will be an accumulation of bradykinin. Bradykinin. The accumulation of bradykinin increases the vascular permeability responsible for the formation of edema if the aminopeptidase $P$ activity is insufficient [12] [17].

We report a case of neurotic angioedema and show the value of careful clinical observation of the absence of biological examinations.

\section{Observation}

This is a 73 years old man, black and hypertensive known. He had an antihypertensive treatments ACE inhibitor and calcium channel blocker. He has been treated with these molecules for at least 6 months. A few months later he consulted because, for 2 days, he presented edema of the face non-pruriginous (Figure 1).

All these signs appeared spontaneously. He has already taken corticosteroid, and antihistamine but no effect. According to the patient's statement, he has no previous antecedent of edema. In spite of the absence of biological examinations, with the medical history of the patient and the clinical manifestation of edema, we have retained the diagnosis of neurotic angioedema. The patient was treated with tranexamic acid $(1 \mathrm{~g} \times 4)$. The evolution was favorable 24 hours after taking the tranexamic acid with disappearance of the edema (Figure 2).

\section{Comments}

This observation adds the cases of secondary neurotic angioedema under ACE inhibitor, published in the literature because fifty cases are already recorded [18]. This case allows us to remember that we must be wary of the possibility of neurotic angioedema in all patients on IEC treatments whose edema can be considered as other origins like allergy; while some localization of the neurotic angioedema may be life-threatening for the patient requiring specific treatment and cessation of treatment with IEC. In addition IEC is a very used hypertensor. First, the age of the patient led to the diagnosis, because the edema secondary to ACE inhibitor manifests itself later, usually after 40 years [18]. Its delay of appearance could explain the acquired origin of the neurotic angioedema but not inherited. 


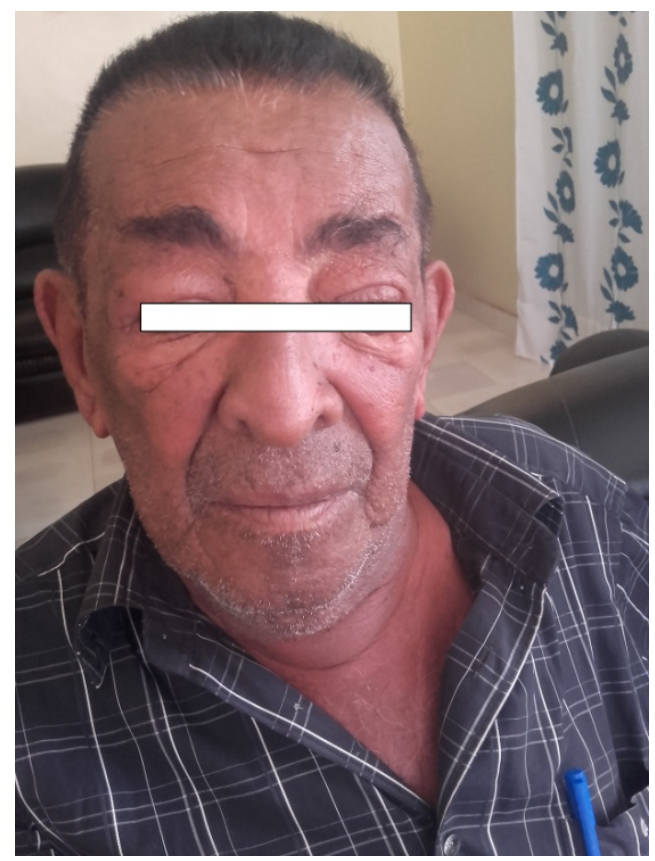

Figure 1. Edema of the face and neck.

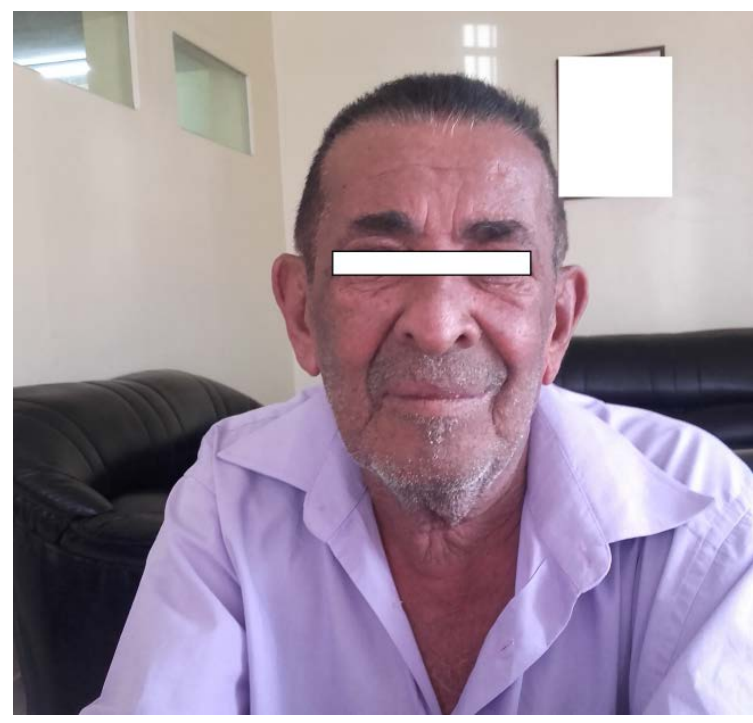

Figure 2. Resorption of edema.

The clinical feature presented by our patient was very evocative even though no clinical manifestations were pathognomonic of angioneurotic edema. Neurotic angioedema is non-inflammatory and non-pruriginous edema of the extremities and neck and face [19]. The clinical evolution presented by our patient was also evocative because the edema appeared spontaneously [20] a few months after treatment, lasted a few days, and regressed in 24 hours [18]. In addition, symptoms disappeared after drug cessation [18]. Its appearance requires certain duration of treatment for there to be an accumulation of bradykinin, also the drug cessation allow the recovery of the function angiotensin-converting enzyme, 
so the recovery of the degradation of bradikynin and disappearance of edema.

According to data from the literature, the time to onset of neurotic angioedema varies from a few weeks to a few years after initiation of treatment [16] [21] and [22] and in 50\% of cases the neurotic angio edema appears a few months after treatment as encountered in our patient [23].

Although the occurrence of cough or other pathologies is a predominant factor in the occurrence of neurotic angioedema, our patient did not experience any side effects of ACE such as cough, kidney failure, hyperkalaemia, dysgeusia, hypotension, cytopenia, rash, or a particular pathology [15].

Biological diagnosis could not be made because biological techniques for the determination of bradykinin, the aminopeptidase $\mathrm{P}$ enzyme, the $\mathrm{Clinh}$ weight and functional assay, and the genetic factor XII and aminopeptidase P [24] is not available.

In view of the clinical manifestations and the inefficacy of the conventional anti-edema treatments [20], the diagnosis of neurotic angioedema is retained, and tranexamic acid has been used because we do not have bradykinin B2 receptor antagonist therapy or the inhibitor concentrate. Tranexamic acid will slow down the process responsible for edema by acting on pasminogen and plasmin as well as on the action of complement [25].

After administration of this molecule and cessation of ACE inhibitor therapy, clinical signs decreased within 24 hours and no recurrences were reported by our patient even though up to 6 months after cessation of ACE inhibitors, angioedema edema may recur.

\section{Conclusion}

Neurotic angioedema may occur at any time in patients with ACE inhibitor. The delay in the management of neurotic angioedema may involve the patient's prognosis, especially if the localization is laryngeal. Therefore, in the absence of biological analyzes to diagnose angioneurotic edema, it is important to make a careful inquiry in order to have a patient or family history and to seek a causative factor, and then characterize the mode of appearance of the edema, the place of predilection of the edema, the characters of the edema, the evolution of the edema. The history of the disease, the patient's history, clinical manifestations and response to treatments may lead to the diagnosis of angioedema neurotic. The cessation of the causative factor and the early administration of an adequate treatment avoid the complication of edema such as dyspnea in the case of laryngeal edema. Patient monitoring is the rule as edema can recur even several months after the crisis.

\section{References}

[1] Bouillet, L. (n.d.) Orphanet: Angio oedème [Internet]. Orphanet. http://www.orpha.net/consor/cgi-bin/OC_Exp.php?lng=FR\&Expert=65

[2] Bowen, T., Cicardi, M., Farkas, H., et al. (2010) International Consensus Algorithm for the Diagnosis, Therapy and Management of Hereditary Angioedema. Allergy, 
Asthma \& Clinical Immunology, 6, 24. https://doi.org/10.1186/1710-1492-6-24

[3] Grigoriadou, S. and Longhurst, H.J. (2009) Clinical Immunology Review Series: An Approach to the Patient with Angio-Oedema. Clinical \& Experimental Immunology, 155, 367-377. https://doi.org/10.1111/j.1365-2249.2008.03845.x

[4] Inomata, N. (2012) Recent Advances in Drug-Induced Angioedema. Allergology International, 61, 545-557. https://doi.org/10.2332/allergolint.12-RAI-0493

[5] Cicardi, M., Aberer, W., Banerji, A., Bas, M., Bernstein, J.A., Bork, K., et al. (2014) Classification, Diagnosis, and Approach to Treatment for Angioedema: Consensus Report from the Hereditary Angioedema. Allergy, 69, 602-616. https://doi.org/10.1111/all.12380

[6] Agostoni, A. and Cicardi, M. (2001) Drug-Induced Angioedema without Urticaria. Drug Safety, 24, 599-606. https://doi.org/10.2165/00002018-200124080-00004

[7] Pecquet, C. (2003) OEdème de Quincke. Ann Dermatol Venerol, 130, 219-224.

[8] Andrejak, M. (2010) Angioedèmes, IEC et sartans. Thérapeutiques en DermatoVénérologie. Cahier 1.

[9] Bouillet, L., Ponard, D., Dumestre, C., et al. (2000) L'oedème angioneurotique acquis: Caractéristques cliniques et biologiques chez neuf patients. Presse Med, 29, 640-644.

[10] Frémeaux-Bacchi, V., Dragon-Durey, M.-A., Blouin, J., Mouthon, L. and Fridman, W.H. (2003) Le complément en médecine interne. Ann Med Int, 154, 529-540.

[11] André, C., André, F., Veysseyre-Balter, C. and Rousset, H. (2003) OEdème angioneurotique acquis induit par la contraception hormonale. Presse Med.

[12] Drouet, C., Ponard, D. and Bouillet, L. (2006) Angio-oedèmes iatrogènes par inhibiteurs de l'enzyme de conversion, antagonistes du récepteur de l'angiotensine, membranes de dialyse. [Iatrogenic Angioedema Due to Estrogen, Angiotensin Conversion Enzyme Inhibitors, Angiotensin Receptor Antagonists and Dialysis Membranes.] La Revue de Médecine Interne, 27, S76-S79.

https://doi.org/10.1016/j.revmed.2006.03.012

[13] Kostis, J.B., Moreyra, A.E. and Kostis, W.J. (2016) Angioedema with Renin Angiotensin System Drugs and Neutral Endopeptidase Inhibitors. Journal of the American Society of Hypertension, 10, 387-389. https://doi.org/10.1016/j.jash.2016.02.017

[14] Cugno, M., Nussberger, J., Cicardi, M. and Agostoni, A. (2003) Bradykinin and the Pathophysiology of Angioedema. International Immunopharmacology, 3, 311-317. https://doi.org/10.1016/S1567-5769(02)00162-5

[15] Morimoto, T., Gandhi, T.K., Fiskio, J.M., Seger, A.C., So, J.W., Cook, E.F., Fukui, T. and Bates, D.W. (2004) An Evaluation of Risk Factors for Adverse Drug Events Associated with Angiotensin-Converting Enzyme Inhibitors. Journal of Evaluation in Clinical Practice, 10, 499-509. https://doi.org/10.1111/j.1365-2753.2003.00484.x

[16] Agostini, A., Cicardi, M., Cugno, M., Zingale, L.C., Gioffré, D. and Nussberger, J. (1999) Angioedma due to Angiotensin-Converting Enzyme Inhibitors. Immunopharmacology, 44, 21-25. https://doi.org/10.1016/S0162-3109(99)00107-1

[17] Cicardi, M., Zingale, L.C., Bergamaschini, L., et al. (2004) Angioedema Associated with Angiotensin-Converting Enzyme Inhibitor Use. Outcome after Switching to a Different Treatment. Archives of Internal Medicine, 164, 910-913. https://doi.org/10.1001/archinte.164.8.910

[18] Garcia-Hejl, C., Harnois, F., El Jahiri, Y., Bigaillon, C., Mennecier, D., Ceppa, F., Thiolet, C. and Fabre, R. (2006) Un cas d'oedème angioneurotique acquis. Ann Biol Clin, 64, 166-169. 
[19] Dumestre-Pérard, C. and Bouillet, L. (2000) Acquisitions récentes concernant une maladie peu fréquente: l'oedème angioneurotique associé à un déficit en $\mathrm{C} 1$ inhibiteur. Lyon Pharm, 51, 14-30.

[20] Borne, M., Borne-Pons, M., Vincenti-Rouquette, I., Lambert, E. and Diraison, Y. (1999) Oèdème angioneurotique et anesthésie: Préparation, thérapeutique et recommandations périopératoires en 1999. Med Armées, 27, 391-398.

[21] Sabroe, R.A. and Black, A.K. (1997) Angiotensin-Converting Enzyme (ACE) Inhibitors and Angiooedema. British Journal of Dermatology, 136, 153-158. https://doi.org/10.1111/j.1365-2133.1997.tb14887.x

[22] O’Ryan, F., Poor, D.B. and Hattori, M. (2005) Intraoperative Angioedema Induced by Angiotensin-Converting Enzyme Inhibitors: Overview and Case Report. Journal of Oral and Maxillofacial Surgery, 63, 551-556.

https://doi.org/10.1016/j.joms.2004.12.010

[23] Fain, O., Mekinian, A., Gobert, D., Khau, C.A. and Javaud, N. (2015) [Drug Induced Angioedema (ACE-Inhibitors and Other)]. La Presse Médicale, 44, 43-47. https://doi.org/10.1016/j.lpm.2014.07.019

[24] Adam, A., Cugno, M., Molinaro, G., Perez, M., Lepage, Y. and Agostoni, A. (2002) Aminopeptidase P in Individuals with a History of Angio-Oedema on ACE Inhibitors. The Lancet, 359, 2088-2089. https://doi.org/10.1016/S0140-6736(02)08914-6

[25] Bouillet, L., Drouet, C., Ponard, D. and Massot, C. (2003) Intérêt du test thérapeutique à l'acide tranexamique dans la prise en charge des angio-œdèmes non allergiques. Rev Méd Interne, 24, Suppl 4. 